\title{
EFEKTIVITAS WEBSITE DESA MALASARI DAN PERAN INTERNET OPINION LEADER (Effectiveness of Malasari Village Website and Role of Internet Opinion Leader)
}

\author{
Siska Mulyawaty ${ }^{1)}$ Pudji Muljono ${ }^{2)}$ Kudang Boro Seminar ${ }^{3)}$ \\ ${ }^{1)}$ Staf Pengajar SMP Al Umanaa Boarding School \\ ${ }^{2)}$ Dosen Fakultas Ekologi Manusia, Institut Pertanian Bogor \\ ${ }^{3)}$ Dosen Fakultas Teknologi Pertanian, Institut Pertanian Bogor \\ e-mail: siskamulyawaty@yahoo.com
}

Naskah diterima: 12 Januari 2016; Direvisi: 18 April 2016; Disetujui: 27 Mei 2016

\begin{abstract}
Utilization of Information and Communication Technology (ICT) is one solution to deliver information of governance and public services optimally to the village level. This research aimed to analyze website visitor characteristics, dimensions of website quality, role of internet opinion leader, and effectivenes of village website, also to analyze the correlation between three variables with effectiveness of village website. This study used correlational approach of quantitative. Data analysis used descriptive and inferential statistical analysis, also t-test analysis. Collecting data used a survey method by spreading e-questionnaire to 40 website visitors of two sample groups, active members of Facebook accounts Pewarta Desa Malasari and commenters on website. Based on the characteristics of website visitors, only indicator of monthly income and frequency of accessing website correlated significantly with effectiveness of village website. Information quality has strongest correlation with the effectiveness of village website, especially on the cognitive effects. The role of internet opinion leaders has no significant correlation with effectiveness of village website. Other findings showed that Facebook account of Pewarta Desa Malasari and Aji Panjalu acted as active internet opinion leaders. Village website can be effective as development information dissemination media by fullfil dimensions of website quality, and maximize the role of internet opinion leaders via social media. The use of social media has become important in supporting the existence of the village website, so it can do further research to see the relationship with the effectiveness of communication.
\end{abstract}

Key words: effectivenness, village website, Facebook, internet opinion leader

\section{PENDAHULUAN}

\section{Latar Belakang}

Sebagai negara kepulauan, menyediakan informasi yang merata kepada masyarakat menjadi suatu tantangan bagi pemerintah Indonesia. Pemanfaatan teknologi informasi dan komunikasi (TIK) berbasis internet merupakan salah satu solusi dalam mewujudkan keadilan bagi seluruh masyarakat untuk mendapatkan informasi mengenai isu-isu pemerintahan dan pelayanan publik yang optimal.

Berbagai kekeliruan dalam memilih pendekatan pembangunan pedesaan menyebabkan Indonesia kehilangan momentum yang paling berharga dalam pembangunan pedesaan. Akibatnya, kondisi infrastruktur makin kurang terpelihara karena terbatasnya kemampuan pemerintah dalam membangun dan merawat infrastruktur yang ada, serta tidak adanya rasa memiliki dari masyarakatnya terhadap infrastruktur yang ada karena mereka tidak menghayati sulitnya membangun atau memelihara infrastruktur (Jamal, 2009).

Lahirnya Undang-Undang Republik Indonesia Nomor 6 Tahun 2014 Tentang Desa, memiliki pertimbangan utama bahwa desa memiliki hak dalam mengatur dan mengurus kepentingan masyarakat setempat dan berperan dalam mewujudkan cita-cita kemerdekaan yang bersatu, berdaulat, adil, dan makmur. Desa merupakan ujung tombak pemerintahan terbawah yang menyimpan potensi untuk memberikan kehidupan yang sejahtera bagi masyarakat setempat. Inti utama dari Undang-Undang Desa adalah pemberdayaan, dimana pemerintah desa bersama masyarakatnya mampu 
mengembangkan potensi desanya sehinggga dapat meningkatkan kualitas kehidupannya secara mandiri, serta untuk aktif berpartisipasi dalam pembangunan nasional.

Untuk melihat kegiatan komunikasi pembangunan yang lebih informatif dan interaktif, penelitian mengenai media internet menjadi relevan, sesuai dengan penelitian Sosiawan (2004) yang memaparkan hasil kajiannya mengenai internet sebagai media komunikasi interpersonal dan massa, Ia menyatakan bahwa internet memiliki fungsi sebagai media komunikasi interpersonal (email dan chatting), dan sebagai media komunikasi massa (website).

Website desa dengan domain desa.id lahir dari inisiatif masyarakat, untuk desa dapat menyuarakan kondisi desa, mempromosikan potensi desa, serta menarik perhatian pihak-pihak yang terkait dengan kebutuhan desa baik pemerintah supra desa maupun sektor swasta, hal ini merupakan tahapan awal menuju Desa Mandiri dan Berdaulat.

Salah satu fungsi website desa dipaparkan dalam penelitian Hartono dan Mulyanto (2010), yang menyatakan bahwa bagi investor, informasi mengenai potensi investasi dan iklim investasi desa sangat diperlukan sebagai bahan pertimbangan dalam pengambilan keputusan lokasi untuk investasi. Tetapi hal ini tidak cukup sampai sebatas ketersediaan informasi saja, diperlukan rangkaian upaya untuk memberikan gambaran yang lebih komprehensif.

\section{Tujuan Penelitian}

1. Menganalisis karakteristik pengakses website, dimensidimensi kualitas website, peran internet opinion leader, dan efektivitas website desa sebagai media penyebaran informasi pembangunan di Desa Malasari Kabupaten Bogor.
2. Menganalisis hubungan antara karakteristik pengakses website dengan efektivitas website desa sebagai media penyebaran informasi pembangunan di Desa Malasari Kabupaten Bogor.

3. Menganalisis hubungan antara dimensi-dimensi kualitas website dengan efektivitas website desa sebagai media penyebaran informasi pembangunan di Desa Malasari Kabupaten Bogor.

4. Menganalisis hubungan antara peran internet opinion leader dengan efektivitas website desa sebagai media penyebaran informasi pembangunan di Desa Malasari Kabupaten Bogor.

\section{KERANGKA BERPIKIR}

Website desa merupakan aplikasi Teknologi Informasi dan Komunikasi (TIK) berbasis internet, yang dimanfaatkan oleh pemerintah desa sebagai media informasi dan komunikasi dengan masyarakat. Namun, masih terdapat masyarakat miskin informasi yang mayoritas berada di daerah pedesaan, tidak sesuai dengan karakteristik media website yang membutuhkan literasi media yang memadai.

Penelitian ini dilakukan untuk mengetahui efektivitas media website sebagai media penyebaran informasi dan komunikasi. Effendy (2005) menyatakan komunikasi untuk dapat dikatakan efektif jika dapat menimbulkan dampak yaitu; 1) Kognitif, yakni meningkatnya pengetahuan komunikan; 2) Afektif, yaitu perubahan pandangan komunikan, karena hatinya tergerak akibat komunikasi; dan 3) Konatif yaitu perubahan perilaku atau tindakan yang terjadi pada komunikan. Efektivitas dalam penelitian ini dikaji dalam dua level komunikasi yaitu interpersonal dan massa, sesuai kajian internet sebagai media komunikasi 
interpersonal dan massa. Komunikasi

interpersonal dikaitkan dengan

peningkatan factor - faktor yang

mendukung efektivitas komunikasi

terutama dalam cyberspace, $\mathbf{x}_{\mathbf{1}}$ : Karakteristik Pengakses Website

keterbukaan (openness), empati, dan $\mathrm{X}_{1.1}$ Usia

mendukung.

$\mathrm{X}_{1.2}$ Jenis kelamin

$\mathrm{X}_{1.3}$ Tingkat pendidikan

$\mathrm{X}_{1.4}$ Pekerjaan

$\mathrm{X}_{1.5}$ Tingkat penghasilan

$\mathrm{X}_{1.6}$ Frekuensi mengakses website

$\mathrm{X}_{2}$ : Kegunaan (Usability)

$\mathrm{X}_{2.1}$ Kemudahan untuk dioperasikan

$\mathrm{X}_{2.2}$ Interaksi dengan website jelas dan dapat di mengerti

$\mathrm{X}_{2.3}$ Kemudahan untuk navigasi

$\mathrm{X}_{2.4}$ Kemudahan menemukan alamat website

$\mathrm{X}_{2.5}$ Tampilan yang atraktif

$\mathrm{X}_{2.6}$ Tepat dalam penyusunan tata letak informasi

$\mathrm{X}_{2.7}$ Tampilan sesuai dengan jenis website pemerintahan

$\mathrm{X}_{2.8}$ Adanya penambahan pengetahuan dari informasi website

$\mathrm{X}_{3}$ : Kualitas Informasi (Information Quality)

$\mathrm{X}_{3.1}$ Menyediakan informasi yang cukup jelas

$\mathrm{X}_{3.2}$ Menyediakan informasi yang dapat dipercaya

$\mathrm{X}_{3.3}$ Menyediakan informasi yang up to date

$\mathrm{X}_{3.4}$ Menyediakan informasi yang relevan

$\mathrm{X}_{3.5}$ Menyediakan informasi yang mudah dibaca dan dipahami

$\mathrm{X}_{3.6}$ Menyediakan informasi yang cukup detail

$\mathrm{X}_{3.7}$ Menyajikan informasi dalam format yang sesuai

$\mathrm{X}_{4}$ : Kualitas Interaksi (Interaction Quality)

$\mathrm{X}_{4.1}$ Mempunyai reputasi yang baik

$\mathrm{X}_{4.2}$ Mendapatkan keamanan untuk melengkapi transaksi

$\mathrm{X}_{4.3}$ Rasa aman dalam menyampaikan data pribadi

$\mathrm{X}_{4.4}$ Kemudahan untuk menarik minat dan perhatian

$\mathrm{X}_{4.5}$ Adanya suasana komunitas

$\mathrm{X}_{4.6}$ Kemudahan untuk memberi masukan (feed back)

$\mathrm{X}_{4.7}$ Tingkat kepercayaan yang tinggi atas informasi yang disampaikan website

$\mathrm{X}_{5}$ : Peran Internet Opinion Leader

$\mathrm{X}_{5.1}$ Asynchronous communication

$\mathrm{X}_{5.2}$ Synchronous communication

$\mathrm{X}_{5.3}$ Sharing

Bagan 1 Kerangka berpikir penelitian "Efektivitas Website Desa sebagai Media Penyebaran Informasi Pembangunan di Desa Malasari Kabupaten Bogor"

\section{METODE PENELITIAN}

Penelitian ini di desain sebagai penelitian desktiptif korelasional, dengan metode survei. Pengumpulan data dilakukan menggunakan kuesioner online
Y: Efektivitas Website Desa

$\mathrm{Y}_{1}$ Efek Kognitif

$\mathrm{Y}_{2}$ Efek Afektif

$\mathrm{Y}_{3}$ Efek Konatif (e-questionnaire), wawancara dan data sekunder. Penelitian dilakukan di Desa

Malasari, Kecamatan Nanggung, Kabupaten Bogor, Provinsi Jawa Barat. Pengambilan dan pengumpulan data dilakukan pada Maret-Mei 2016. Teknik 


\begin{tabular}{cccc}
\hline Cukup & 30.0 & 40.0 & 57.5 \\
Rendah & 0.0 & 0.0 & 0.0 \\
\hline
\end{tabular}

Pada dimensi kualitas informasi (information quality), jenis nformasi yang ditampilkan telah sesuai dengan tujuan utama yaitu informasi pembangunan dan potensi desa, serta sesuai dengan keberadaan website malasari.desa.id yang masih dalam tahap awal pengembangan sehingga lebih menonjolkan layanan informasi, dibandingkan layanan komunikasi dan transaksi.

Fasilitas kolom komentar pada website, mempermudah interaksi serta memberikan masukan (feedback) antara pengakses dengan pengelola (admin). Berdasarkan observasi yang dilakukan pada website malasari.desa.id, artikel yang mendapat banyak komentar dari pengakses adalah yang berkaitan dengan potensi Desa Wisata Malasari, seperti artikel Regenerasi Tradisi Seni; Upaya Merawat Budaya (9 komentar), From Ausie to Malasari: Rabu Seru Bersama Tamu dari Negeri Kangguru (6 komentar), dan Sawah-Sawah Terasering Malasari yang Masih Diberkati (5 komentar).

\section{Peran Internet Opinion Leader}

Dalam membedakan bentuk komunikasi bermedia internet dengan media klasik oleh opinion leader, maka penulis menggunakan konsep-konsep komunikasi yang khas dalam media internet, yaitu: 1) asynchronous communication (komunikasi asinkronis) seperti $e$-mail; 2) synchronous communication (komunikasi sinkronis) seperti fasilitas Internet Relay Chat (Effendi, 2010); dan 3) Sharing, melakukan sharing, sudah bukan rahasia lagi jika setiap pemilik akun Facebook merasa perlu meluangkan beberapa menit untuk membagi informasi yang mereka nilai penting untuk dipublikasikan (Sosiawan, 2011). Sharing/share merupakan karakter lainnya dari media sosial, yang menunjukkan bahwa khalayak aktif menyebarkan konten sekaligus mengembangkannya.

Tabel 3 Jumlah dan Persentase

Responden Berdasarkan Peran Internet

Opinion Leader

\begin{tabular}{lcccc}
\hline \multirow{2}{*}{$\begin{array}{l}\text { Peran Internet } \\
\text { Opinion Leader }\end{array}$} & \multicolumn{4}{c}{ Jumlah dan Persentase } \\
\cline { 2 - 5 } & \multicolumn{3}{c}{ Ya } & \multicolumn{3}{c}{ Tidak } \\
\cline { 2 - 5 } & (org) & (\%) & (org) & (\%) \\
\hline $\begin{array}{l}\text { Asynchronous } \\
\text { communication }\end{array}$ & 15 & 37.5 & 25 & 62.5 \\
$\begin{array}{l}\text { Synchronous } \\
\text { communiation }\end{array}$ & 19 & 47.5 & 21 & 52.5 \\
Sharing & 24 & 60.0 & 16 & 40.0 \\
\hline
\end{tabular}

Pada Tabel 3 diketahui sebanyak 15 orang mendapatkan e-mail yang menyarankan untuk mengakses website malasari.desa.id, penggunaan e-mail lebih sedikit dibandingkan chatting dan sharing, hal ini dapat dikarenakan sifat $e$ mail dimana pengirim dan penerima pesan tidak berada pada tempat dan waktu yang bersamaan, sehingga terdapat delay yang lama sehingga tidak efektif.

Sedangkan, sebanyak 19 orang $(47.5 \%)$ responden mendapat bentuk komunikasi synchronous communiation berupa chatting melalui media sosial yang menyarankan untuk mengakses website malasari.desa.id. Komunikasi dalam media sosial tak terikat waktu, siang ataupun malam, pihak yang terlibat didalamnya tetap bisa terlibat aktif, juga tak terikat ruang, dengan siapapun di penjuru dunia pihak yang terlibat di dalamnya bisa berkomunikasi (Watie, 2011).

Dari hasil penelitian, bentuk komunikasi online yaitu sharing tampak paling efektif dalam membantu menyebarkan informasi pembangunan desa dan meningkatkan popularitas website malasari.desa.id, sebanyak 24 orang $(60.0 \%)$ mengakses website karena mendapat sharing tautan (link) dari para internet opinion leader. Meskipun lebih bersifat satu arah dan ditujukan pada 
khalayak luas, namun membagi informasi dalam bentuk tautan (link), mempermudah dan mengarahkan khalayak untuk meng-klik tautan tersebut, selain itu tautan (link) tersebut dapat dilihat khalayak kapanpun pada timeline media sosialnya.

\section{Efektivitas Website Desa sebagai Media Penyebaran Informasi Pembangunan di Desa Malasari Kabupaten Bogor}

Internet sebagai media komunikasi memiliki penawaran interaktif yang dinamis terhadap penggunanya, melebihi interaksi pada televisi dan radio (yang terbatas pada satu program dan isi materi acara). Bahkan, internet memberikan penawaran pencarian informasi yang diinginkan menggunakan kata kunci (keywords) (Darmawan, 2013).

Dengan keunggulan internet tersebut, maka efek komunikasi bermedia internet menjadi lebih bervariasi, dalam penelitian ini, penulis mencoba melihat efektivitas media internet yaitu website dalam kajian komunikasi massa dan komunikasi interpersonal. Efek dari pesan yang disebarkan melalui media massa meliputi efek kognitif, efek afektif, dan efek konatif (Abidin, 2015).

Dari Tabel 4 dapat diketahui, efek kognitif berada diantara kategori tinggi dan cukup (50.0\%). Efek kognitif dalam penelitian ini terdiri dari indikator pemahaman, proses belajar, keterampilan kognitif, dan keterbukaan (openness).

Tabel 4 Kategorisasi dan Persentase Responden Berdasarkan Efektivitas Website Desa

\begin{tabular}{cccc}
\hline Kategori & $\begin{array}{c}\text { Efek } \\
\text { Kognitif } \\
(\boldsymbol{\%})\end{array}$ & $\begin{array}{c}\text { Efek } \\
\text { Afektif } \\
(\boldsymbol{\%})\end{array}$ & $\begin{array}{c}\text { Efek } \\
\text { Konatif } \\
(\boldsymbol{\%})\end{array}$ \\
\hline Tinggi & 50.0 & 47.5 & 45.0 \\
Cukup & 50.0 & 52.5 & 55.0 \\
Rendah & 0.0 & 0.0 & 0.0 \\
\hline
\end{tabular}

Efek afektif berada pada kategori cukup $(52.5 \%)$, terdiri dari indikator kepuasan, rasa suka, dan empati. Indikator rasa suka mendapat tanggapan yang paling rendah, hal ini dikarenakan sebagian besar pengakses website telah memiliki referensi yang cukup mengenai tampilan sebuah website yang baik, sehingga untuk wesbite malasari.desa.id dari segi tampilan dan desain website dinilai masih sederhana serta navigasi yang belum tersusun dengan baik.

Efek konatif berada dalam kategori cukup $(55.0 \%)$, dalam penelitian ini dikaitkan dengan bentuk partispasi pengakses website, yang terdiri dari partisipasi fisik dan online, bagi pengakses yang bukan merupakan warga Desa Malasari atau berdomisil di luar daerah Bogor, bentuk partisipasi online lebih memungkinkan untuk dilakukan, yaitu dalam bentuk dukungan terhadap keberadaan website malasari.desa.id, seperti mengisi kolom komentar pada website baik berupa dukungan maupun saran, serta bentuk partisipasi online lainnya melalui media sosial, seperti memberi like, comment, share, dan retweet, guna meningkatkan popularitas atau rating website malasari.desa.id, sehingga lebih banyak pihak yang mengakses website.

\section{Hubungan antara Karaktersitik Pengakses Website dengan Efektivitas Website Desa}

Komunikasi pembangunan akan lebih berhasil mencapai sasaran, serta dapat menghindarkan kemungkinan efekefek yang tidak diinginkan, dengan memperkecil kesenjangan efek yang ditimbulkan oleh kekeliruan cara-cara komunikasi memakai strategi komunikasi pembangunan yang dirumuskan sedemikian rupa, salah satunya pengenalan para pemimpin opini (opinion leader) di kalangan lapisan masyarakat yang berkekurangan (disadvantage), dan meminta bantuan mereka untuk menolong mengkomunikasikan pembangunan (Istiyanto, 2011). 
Asumsi-asumsi pada Model Komunikasi Dua Tahap adalah bahwa pesan-pesan media massa tidak seluruhnya langsung mengenai audience, dan audience dianggap tidak banyak bersentuhan dengan media massa. Audience yang diasumsikan pada model ini sesuai dengan lapisan masyarakat yang miskin informasi, yaitu mereka yang dikelilingi oleh informasi yang berlimpah dan kemudahan akses memperolehnya, namun tidak tahu menggunakannya; dan mereka yang tidak tahu bagaimana dan di mana mendapatkan informasi dan tidak mengerti nilai informasi (Goulding dalam Laksmi, 2002).

Pada Tabel 5 diketahui bahwa hanya dua indikator yang memiliki hubungan nyata dan positif dengan efektivitas website desa yaitu pengahasilan bulanan dan frekuensi mengakses website. Penghasilan bulanan memiliki tingkat hubungan yang sedang dengan efek konatif yaitu partisipasi online, semakin tinggi penghasilan pengakses website maka semakin tinggi pula partisipasi online yang dilakukan, yaitu dapat berupa sharing tautan website agar lebih banyak masyarakat yang mengetahui informasi pembangunan Desa Malasari dan mengakses website-nya.

Tabel 5 Nilai Koefisien Korelasi Rank Spearman Dan P-Value Hubungan antara Karakteristik Pengakses Website dengan Efektivitas Website Desa

\begin{tabular}{|c|c|c|c|c|c|c|c|c|c|}
\hline \multirow{4}{*}{$\begin{array}{c}\text { Karakteristik } \\
\text { Pengakses Website }\end{array}$} & \multicolumn{9}{|c|}{ Efektivitas Website Desa } \\
\hline & \multicolumn{4}{|c|}{ Efek Kognitif } & \multicolumn{3}{|c|}{ Efek Afektif } & \multicolumn{2}{|c|}{ Efek Konatif } \\
\hline & $\begin{array}{l}\text { Pema- } \\
\text { haman }\end{array}$ & $\begin{array}{l}\text { Proses } \\
\text { belajar }\end{array}$ & $\begin{array}{l}\text { Keteram- } \\
\text { pilan kog. }\end{array}$ & $\begin{array}{c}\text { Keter- } \\
\text { bukaan }\end{array}$ & $\begin{array}{c}\text { Kepu- } \\
\text { asan }\end{array}$ & Rasa suka & Empati & $\begin{array}{c}\text { Partisipasi } \\
\text { fisik }\end{array}$ & $\begin{array}{c}\text { Partisipasi } \\
\text { online }\end{array}$ \\
\hline & $\mathbf{r}_{\mathbf{s}}$ & $\mathbf{r}_{\mathbf{s}}$ & $\mathbf{r}_{\mathbf{s}}$ & $\mathbf{r}_{\mathbf{s}}$ & $\mathbf{r}_{\mathbf{s}}$ & $\mathbf{r}_{\mathbf{s}}$ & $\mathbf{r}_{\mathbf{s}}$ & $\mathbf{r}_{\mathrm{s}}$ & $\mathbf{r}_{\mathbf{s}}$ \\
\hline Usia & -0.252 & -0.039 & -0.054 & -0.165 & -0.236 & 0.074 & -0.120 & -0.57 & 0.046 \\
\hline Pendidikan terakhir & -0.074 & 0.115 & 0.154 & 0.032 & -0.288 & -0.224 & -0.252 & 0.002 & 0.249 \\
\hline Penghasilan bulanan & 0.102 & 0.163 & 0.169 & 0.221 & -0.222 & 0.136 & -0.200 & 0.287 & $0.452 * *$ \\
\hline \multirow{2}{*}{$\begin{array}{c}\text { Frekuensi mengakses } \\
\text { website }\end{array}$} & 0.144 & 0.051 & 0.003 & -0.039 & 0.219 & $0.377 *$ & 0.052 & 0.301 & 0.040 \\
\hline & $\mathbf{p}$ & $\mathbf{p}$ & $\mathbf{p}$ & $\mathbf{p}$ & $\mathbf{p}$ & $\mathbf{p}$ & $\mathbf{p}$ & $\mathbf{p}$ & $\mathbf{p}$ \\
\hline Jenis kelamin & 0.551 & 0.722 & 0.290 & 0.941 & 0.375 & 0.600 & 0.790 & 0.420 & 0.599 \\
\hline Pekerjaan & 0.651 & 0.787 & 0.907 & 0.589 & 0.697 & 0.854 & 0.296 & 0.939 & 0.969 \\
\hline
\end{tabular}

Pengakses website dengan kategori penghasilan tinggi yaitu diatas Rp. 3 Juta memang mayoritas bukan merupakan masyarakat lokal Desa Malasari, melainkan masyarakat luar desa. Pengakses website yang merupakan masyarakat lokal memiliki penghasilan antara Rp. 1 Juta - Rp. 3 Juta.

Pengguna internet yang memiliki penghasilan tinggi memiliki sambungan internet pribadi, sehingga memiliki keleluasaan dan ketenangan dalam melakukan akses, karena tidak harus berbagi waktu dengan pengguna lain (Andarwati \& Sankarto, 2005). Penelitian lain menunjukkan bahwa responden yang tergolong berpendapatan menengah yaitu diatas tiga juta per bulan, secara asumtif membawa implikasi memiliki keleluasaan cukup di dalam melakukan akses internet (Adi, 2013).

Indikator lain dari karakteristik pengakes website yang memiliki hubungan nyata adalah frekuensi 
mengakses website, namun dalam tingkat hubungan yang rendah atau lemah, Pada indikator ini, frekuensi mengakses website sebagian besar berada pada kategori rendah yaitu kurang dari sekali seminggu, sedangkan pada kategori sedang yaitu sekali seminggu, di dominasi oleh pengakses yang merupakan masyarakat lokal Desa Malasari.

\section{Hubungan antara Dimensi-Dimensi Kualitas Website dengan Efektivitas Website Desa}

Dimensi kualitas informasi (information quality) merupakan dimensi yang telah diteliti sejak WebQual versi pertama (WebQual 1.0), menurut Simarmata dalam Irawan (2012) menyatakan bahwa internet adalah kelompok atau kumpulan dari jutaan komputer yang dapat melakukan pertukaran informasi dengan adanya sekumpulan protokol. Dalam kajian komunikasi, Shannon and Weaver menyatakan informasi sebagai pesan dalam sistem komunikasi, dari sender (S), melalui saluran komunikasi, kepada receiver $(\mathrm{R})$. Dari Tabel 6 dapat diketahui bahwa dimensi kualitas informasi (information quality) memiliki hubungan yang paling kuat diantara dua dimensi lainnya.

Website malasari.desa.id dapat menjadi media pembelajaran berbasis TIK bagi pengakses website untuk memahami proses pembangunan Desa Malasari, untuk dapat menghasilkan e-learning yang menarik dan diminati, Onno W. Purbo mensyaratkan tiga hal yang wajib dipenuhi dalam merancang e-learning yaitu: sederhana, personal, dan cepat (Yazdi, 2012).

Tabel 6 Nilai Koefisien Korelasi Rank Spearman antara Dimensi-Dimensi Kualitas Website dengan Efektivitas Website Desa

\begin{tabular}{lc}
\hline \multicolumn{1}{c}{$\begin{array}{c}\text { Dimensi-Dimensi } \\
\text { Kualitas Website }\end{array}$} & $\boldsymbol{r}_{\boldsymbol{s}}$ \\
\hline Kegunaan & $0.699^{* *}$ \\
Kualitas Informasi & $0.763^{* *}$ \\
Kualitas Interaksi & $0.684^{* *}$ \\
\hline$* *$ Korelasi signifikan pada level 0.01 &
\end{tabular}

Berkaitan dengan dimensi kegunaan, tampilan sederhana telah diterapkan pada website malasari.desa.id dengan tata letak informasi yang sesuai, tampilan yang mudah dimengerti, dan mudah untuk bernavigasi, sehingga pengakses tidak memerlukan banyak waktu untuk terlebih dahulu memahami tampilan website. Syarat personal dan kecepatan yang berkaitan dengan interaksi antara pengakses dan pengelola website, masih harus di tingkatkan untuk website malasari.desa.id, namun dengan adanya media sosial Facebook Pewarta Desa Malasari dapat menunjang interaksi yang lebih personal dengan beberapa pengakses website.

Kualitas informasi menunjukkan hubungan yang lebih kuat pada indikator efek kognitif, yaitu meningkatnya pemahaman, proses belajar, keterampilan kogntif, dan keterbukaan. Informasi yang cukup detail semakin meingkatkan pemahaman pengakses mengenai pembangunan di Desa Malasari. Informasi dalam website selalu dilengkapi oleh foto atau gambar yang relevan, tanggal dan waktu kejadian, dan hasil wawancara dengan warga atau aparat desa. Informasi yang dapat dipercaya, mudah dibaca dan dipahami semakin meingkatkan keterampilan kognitif dan pembelajaran pengakses website.

Pada efek afektif, pengakses merasa puas dengan informasi dalam website malasari.desa.id, jenis informasi telah sesuai dengan identitas website sebagai media penyebaran informasi pembangunan dan potensi desa, serta konsisten menampilkan informasi yang relevan. Efek konatif lebih dominan pada partisipasi fisik dibandingkan partisipasi online, hal tersebut karena informasi 
dalam website sangat berguna bagi masyarakat lokal Desa Malasari yang mengakses website untuk mengetahui kegiatan yang telah dan akan dilakukan di Desa Malasari. Namun, dibandingkan dengan media website, untuk penyebaran informasi diantara masyarakat lokal Desa Malasari masih menggunakan komunikasi interpersonal maupun kelompok berupa musyawarah.

Kualitas interaksi memiliki hubungan yang tinggi dengan indikator keterbukaan (openness) pada efek kognitif, hal tersebut berkaitan dengan komunikasi interpersonal dalam perspektif komunikasi cyberspace, media internet membantu meningkatkan keterbukaan individu yang tidak berani mengungkapkan sesuatu pesan secara langsung, terbantu untuk mengungkapkannya secara tertulis (Fardiah, 2002).

Salah satu hambatan dalam CMC adalah tidak adanya dukungan kontak fisik, sehinggga keterbukaan dalam komunikasi tidak berada pada derajat yang tinggi dan ini memungkinkan komunikasi menjadi tertutup tanpa ada kejelasan untuk mengenal pribadi masingmasing person pengguna (Sosiawan, 2004). Dalam penelitian ini, terdapat temuan yang berbeda, yaitu indikator adanya suasana lebih personal atau kedekatan saat berinteraksi memiliki hubungan yang cukup tinggi dengan ketiga aspek efektivitas, hal tersebut dikarenakan adanya suatu komunitas besar yang melatarbelakangi keberadaan website desa.id di Indonesia yaitu LSM Gerakan Desa Membangun, dan mengingat usia website malasari.desa.id yang masih baru, sehingga pengakses website masih banyak yang berasal dari komunitas tersebut dan masyarakat lokal Desa Malasari.

Berkaitan dengan efek konatif yang diukur dalam penelitian ini ialah tingkat partisipasi pengakses website, baik partisipasi fisik maupun online keduanya memiliki hubungan nyata dengan kualitas interaksi, namun partisipasi online berhubungan lebih tinggi dibandingkan partisipasi fisik. Bentuk partisipasi online yang dapat dilakukan oleh pengakses website ialah menyarankan orang lain untuk mengakses website malasari.desa.id, sehingga website menjadi semakin popular dan lebih banyak orang yang mengakses termasuk pihak-pihak yang berkaitan dengan pembangunan Desa Malasari seperti pemerintah maupun investor dari pihak swasta.

\section{Hubungan antara Peran Internet Opinion Leader dengan Efektivitas Website Desa}

Sebuah penelitian melihat peran internet opinion leader pada media sosial Twitter dalam kajian komunikasi pemasaran, menyebut istilah lain yang mungkin lebih dapat diterima yaitu Digital Influence atau Buzzer (Hananto, 2014). Penelitian Scafer and Taddicken (2015) menemukan peran komunikasi baru dalam opinion leadership yang disebut Mediatized Opinion Leader yang menggunakan baik media massa maupun media online secara signifikan lebih sering daripada kelompok lainnya.

Dari Tabel 6 diketahui bahwa peran internet opinion leader tidak memiliki hubungan nyata dengan efektivitas website malasari.desa.id sebagai media penyebaran informasi pembangunan Desa Malasari. Berdasarkan obervasi yang dilakukan, masih rendahnya jumlah pengakses website malasari.desa.id selama penyebaran kuesioner online menunjukkan belum maksimalnya peran internet opinion leader dalam menyarankan pengguna internet untuk mengakses website malasari.desa.id. 
Tabel 7 Nilai $P$-Value Hubungan antara Peran Internet Opinion Leader dengan Efektivitas Website Desa

\begin{tabular}{cccc}
\hline & \multicolumn{3}{c}{ Peran Internet Opinion Leader } \\
\cline { 2 - 3 } Efektivtias & Asynch- & Synch- & Sharing \\
Website Desa & comm. & comm.
\end{tabular}

\begin{tabular}{lccc}
\hline $\begin{array}{l}\text { Efek Kognitif } \\
\text { Pemahaman }\end{array}$ & 0.744 & 4.017 & 2.467 \\
$\begin{array}{l}\text { Proses Belajar } \\
\text { Keterampilan }\end{array}$ & 1.202 & 0.327 & 0.444 \\
$\begin{array}{l}\text { Kogntif } \\
\text { Keterbukaan } \\
\text { (Openness) }\end{array}$ & 0.372 & 6.686 & $0.019 *$ \\
\hline $\begin{array}{l}\text { Efek Afektif } \\
\text { Kepuasan }\end{array}$ & 1.710 & 1.229 & 0.714 \\
$\begin{array}{l}\text { Rasa Suka } \\
\text { Empati } \\
\text { (Emphaty) }\end{array}$ & 0.454 & 1.942 & 1.574 \\
\hline $\begin{array}{l}\text { Efek Konatif } \\
\text { Partisipasi }\end{array}$ & 0.145 & 3.796 & 1.648 \\
$\begin{array}{l}\text { Fisik } \\
\text { Partisipasi }\end{array}$ & 2.006 & 6.356 & 3.852 \\
Online & 2.713 & 6.688 & 0.824 \\
\hline *Korelasi signifikan pada level 0.05 & & \\
\end{tabular}

Dalam penelitian ini, dilakukan metode observasi dan investigasi secara komprehensif dalam menentukan opinion leader dalam komunitas virtual yaitu 1) melakukan observasi untuk menemukan orang yang aktif dan memiliki banyak follower dalam forum/komunitas mengenai suatu topik tertentu, 2) membuat investigasi online (dan offline) kepada para follower mengenai topik tertentu dan menanyakan siapakah yang mereka anggap sebagai opinion leader, 3) meringkas dan dan mengkombinasikan kedua jenis data dan mengidentifikasi satu atau beberapa opinion leader (Zhang \& Dong, 2008).

Dari hasil observasi dan investigasi (melalui e-questionnaire) ditemukan beberapa akun yang berperan sebagai internet opinion leader berkaitan dengan penyebaran keberadaan website malasari.desa.id serta informasi pembangunan desanya, yaitu: akun Pewarta Desa Malasari (Asynchronous communication), Sahdi Sutisna (nama akun: Aji Panjalu) (Synchronous communication dan Sharing).

\section{Perbedaan Efektivitas Website Desa sebagai Media Penyebaran Informasi Pembangunan di Desa Malasari Kabupaten Bogor}

Analisis data berupa Uji Beda $T$ Test dilakukan pada penelitian ini untuk mengetahui perbedaan dua kelompok populasi yaitu anggota Facebook aktif (23 responden) dan pengisi kolom komentar (17 responden) dalam efektivtitas website malasari.desa.id sebagai media penyebaran informasi desa, yang terdiri dari efek kognitif, efek efektif, dan efek konatif.

Tabel 8 Nilai Uji Beda Efektivitas

Website Desa pada Anggota Facebook Aktif dan Pengisi Kolom Komentar

Wesbite

\begin{tabular}{llc}
\hline $\begin{array}{c}\text { Efektivitas } \\
\text { Website Desa }\end{array}$ & T-test & Keterangan \\
\hline Efek Kognitif & 0.903 & Tidak terdapat perbedaan \\
Efek Afektif & $0.025 *$ & Terdapat perbedaan \\
Efek Konatif & 0.433 & Tidak terdapat perbedaan \\
\hline *p-value $\geq 0.05=$ berbeda nyata &
\end{tabular}

Hasil uji beda pada Tabel 8 menunjukkan hanya efek afektif yang memiliki perbedaan yang nyata. Indikator yang memiliki perbedaan yang signifikan adalah indikator rasa suka terhadap website malasari.desa.id, dan didominasi oleh pengakses website yang merupakan anggota Facebook Pewarta Desa Malasari. Rasa suka terhadap website dalam penelitian ini lebih diarahkan pada tampilan informasi website. Pengakses website yang merupakan anggota Facebook, mayoritas adalah masyarakat lokal Desa Malasari, sehingga rasa suka yang timbul disertai pula dengan dukungan akan keberadaan website desanya. 
ISSN 1693-3699

\section{SIMPULAN DAN SARAN}

\section{Simpulan}

Berdasarkan hasil dan pembahasan, dapat disimpulkan bahwa:

1. Pengakses website malasari.desa.id sebagian besar berusia antara 18-35 tahun, berjenis kelamin pria, memiliki pendidikan formal sarjana, bekerja sebagai wiraswasta, memiliki penghasilan antara Rp. 1 Juta Rp. 3 Juta, dan kurang dari sekali seminggu mengakses website. Dimensi-dimensi kualitas website, yaitu kegunaan (usability), kualitas informasi (information quality), kualitas interaksi (interaction quality) dalam kategori cukup. Peran internet opinion leader paling banyak dilakukan adalah sharing tautan informasi website.

2. Tidak terdapat hubungan nyata antara karakteristik pengakses website malasari.desa.id, dengan efektivitas website desa. Pengakses yang memiliki penghasilan tinggi memiliki hubungan nyata dengan efek konatif yaitu partisipasi online. Tingkat Frekuensi mengakses website sekali seminggu berhubungan nyata dengan efek afektif yaitu rasa suka terhadap tampilan informasi pada website malasari.desa.id.

3. Dimensi-dimensi kualitas website, yang terdiri dari kegunaan (usability), kualitas informasi (information quality), dan kualitas interaksi (interaction quality) memiliki hubungan nyata dengan efektivitas website malasari.desa.id sebagai media penyebaran informasi pembangunan desa. Kualitas informasi (information quality) memiliki hubungan yang lebih
Jurnal Komunikasi Pembangunan Juli 2016 Vol 14, No 2

kuat dibandingkan dua dimensi lainnya, terutama perubahan pada efek kognitif pengakses website.

4. Peran internet opinion leader tidak memiliki hubungan nyata dengan efektivitas website malasari.desa.id. Namun, indikator sharing berhubungan nyata dengan salah satu indikator efek kognitif yaitu keterbukaan (openness). Temuan lainnya adalah didapatkan dua akun sebagai internet opinion leader yang aktif yaitu akun Facebook Pewarta Desa Malasari, dan akun Aji Panjalu.

\section{Saran}

Saran yang dapat disampaikan berdasarkan hasil penelitian adalah:

1. Bagi penelitian selanjutnya, penggunaan media sosial sebagai penunjang keberadaan website desa dapat dijadikan sebuah variabel tersendiri untuk diteliti lebih jauh guna melihat hubungannya dengan efektivitas komunikasi, karena media sosial dapat meningkatkan isu dan popularitas sebuah website desa, serta menjadi media interaksi yang lebih personal dengan pengakses website.

2. Bagi pemerintah Desa Malasari dan pengelola website, sebaiknya lebih maksimal dalam mengembangkan website malasari.desa.id, yaitu penambahan informasi mengenai potensi utama desa secara menyeluruh, serta penyusunan dan pembenahan Sistem Informasi Desa (SID) agar dapat menampilkan profil desa secara akurat dan lengkap.

3. Bagi pihak pemerintah maupun swasta yang berkaitan dengan penyediaan jaringan internet $\mathrm{di}$ Kabupaten Bogor, diharapkan 
dapat meningkatkan kualitas jaringan internet. Jaringan internet sangat dibutuhkan desa tidak hanya untuk pengelolaan website dan peningkatan penggunaan Teknologi Informasi dan Komunikasi (TIK) bagi masyarakat desa, melainkan sebagai cara yang efektif dan efisien untuk mensejajarkan desa tertinggal dengan desa yang sudah maju guna memenuhi tuntutan Undang-Undang Desa No. 6 Tahun 2014.
Juli 2016 Vol 14, No 2

\section{DAFTAR PUSTAKA}

Abidin YZ. 2015. Manajemen Komunikasi-Filosofi, Konsep, dan Aplikasi. Bandung (ID): Pustaka Setia.

Adi TN. 2013. Studi deskriptif tentang perilaku pemanfaatan internet di kalangan pengguna internet pemula usia dewasa di Purwokerto. Acta Durna [internet]. [diunduh 2016 Juni 9]; 9(2): 80-95: http://www.ejurnal.com/2014/05/studideskriptif-tentang-perilaku.html

Andarwati SR, Sankarto B. 2005. Pemenuhan kepuasan penggunaan internet oleh peneliti Badan Litbang pertanian di Bogor. $J$ Perpustakaan Pertanian [internet]. [diunduh 2016 Juni 9]; 14(1): 10-17: http://digilib.litbang .pertanian.go.id/v2/katalog/majala $\mathrm{h} / \mathrm{J} /$ jurnal-perpustakaan-pertanian/14/1/2005/pemenuhan-kepuasanpenggunaan-internet-oleh-penelitibadan-litbang-pertanian-di-bogor-

Aprilia SN, Wijaya AF, Suryadi. 2014. Efektivitas website sebagai media e-government dalam meningkatkan pelayanan elektronik pemerintah daerah (studi pada website pemerintah daerah kabupaten jombang). Wacana [internet]. [diunduh 2015 Sept 9]; 17 (3): 126-135. E-ISSN 23381884: http://wacana.ub.ac.id/index .php/wacana/article/view/313

Bungin B. 2010 Metodologi Penelitian Kuantitatif. Jakarta (ID) : Kencana Prenada Media Grup.

Darmawan D. 2013.Pendidikan Teknologi Informasi dan Komunikasi Teori dan Aplikasi. Bandung (ID): PT Remaja Rosdakarya Offset.

Effendi M. 2010. Peranan internet sebagai media komunikasi. J Komunika [internet]. [diunduh 2015 Des 21]; 
4(1): 130-142. ISSN: 1978-1261: http://downlo

ad.portalgaruda.org/article.php?art icle $=49246 \& v a l=391$

Fardiah D. 2002. Komunikasi antar persona: perspektif komunikasi cyberspace. J Mediator [internet]. [diunduh 2015 Des 21]; 3(1): 6371. ISSN: 1411-5883: http://ejournal.unisba.ac.id /index.php/mediator/article/view/7 $87 / 418$

Hananto P. 2014. Opinion leader versus new opinion leader dalam komunikasi pemasaran (studi kasus selebtwit di twitter untuk komunikasi pemasaran). $J$ Interaksi [internet]. [diunduh 2016 Jan 11]; 3(2): 140-153: http://ejournal.undip.ac.id/index.p hp/interaksi/article/view/8780

Hartono UD, Mulyanto E. 2010. Electronic governmnent pemberdayaan pemerintahan dan potensi desa berbasis web. $J$ Teknologi Informasi [internet]. [diunduh 2015 Okt 2]; 6(1). ISSN 1414-9999: http://research .pps.dinus.ac.id/li

Irawan C. 2012. Evaluasi kualitas website pemerintah daerah dengan menggunakan WebQual (studi kasus pada kabupaten ogan ilir). $J$ Sistem Informasi [internet]. [diunduh 2015 Des 18]; 4(2): http://ejournal. unsri.ac.id /index.php/jsi/index

Istiyanto B. 2011. Komunikasi pemerintah daerah dalam program pembangunan daerah wisata pantai pascabencana. $J$ Ilmu Komunikasi [internet]. [diunduh 2015 Des 11]; 9(1): 16-27: http://repository.upnyk.ac .id/1748/1/BEKTI.pdf

Jamal E. 2009. Membangun momentum baru pembangunan pedesaan di indonesia. $J$ Litbang Pertanian [internet]. [diunduh 2016 Jan 7];
Juli 2016 Vol 14, No 2

28(1):http://pustaka.litbang.pertani an.go.id/publikasi/p3281092.pdf

Laksmi, M.A. 2002. Kemiskinan informasi pada masyarakat marjinal di Indonesia. $J \quad A l$ Maktabah [internet]. [diunduh 2016 Jul 19]; 4(2): 93-104: http://journal.uinjkt.ac.id/al-mak tabah/article/viewFile/1635/137

Puryanto. 2013. Pembangunan website pada desa nangsri. Seminar Riset Unggulan Nasional Informatika dan Komputer FTI UNSA 2013 [internet]. [diunduh 2015 Okt 2]; 2(1): http://download.portalg aruda.org/article.php?article $=2687$ $58 \&$ val $=7111 \&$ title $=$ Pembanguna n\%20Website\%20Pada\%20Desa $\% 20$ Nangsri

Sanjaya I. 2012. Pengukuran kualitas layanan website kementerian kominfo dengan menggunakan metode WebQual 4.0. J Penelitian IPTEK-KOM [inter net]. [diunduh 2015 Des 27]; 14(1): 1-13: https://www. acade mia.edu/5014124

Sosiawan EA. 2004. Kajian internet sebagai media komunikasi interpersonal dan massa. J Ilmu Komunikasi [internet]. [diunduh 2015 Des 5]; 1(1): 15-28. ISSN 1693-3029: https://ermafpsi2010 .files.wordpress.com/2011/10/psiinternet-erma1.pdf 2011. Penggunaan situs jejaring sosial sebagai media interaksi dan komunikasi di kalangan mahasiswa. J Ilmu Komunikasi [internet]. [diunduh 2016 Jan 6]; 9(1): 60-75: http://repository.upnyk.ac.id/1983/ 1/EDWI.pdf

Scafer M, Taddicken M. 2015. Mediatized opinion leaders: new patterns of opinion leadership in new media environments? International J of Communica- 
tion [internet]. [diunduh 2016 Nop 1]; 9(1): 960-981: E-ISSN 19328036.ijoc.org/index.php/ ijoc/article/view/2778

Sulistyo DK, Herlan PN, Firdaus YAW. 2008. Analisis kajian standa-risasi isi situs web pemerintah daerah kabupaten/kota. Seminar Nasional Informatika 2008 [internet]. [diunduh 2016 Juni 6]; 55-62. ISSN: 1979-2328: repository.upnyk.ac.id/.../8_Analis is_Kajian_Standarisasi_Isi_Situs...

Watie EDS. 2011. Komunikasi dan media sosial (communications and social media). The Messenger [internet]. [diunduh 2016 Jan 6]; 3(1): 71-76: http://journal.usm.ac.id/elibs/USM _25a3komunikasi\%20dan\%20med ia\% 20sosial.pdf

Yazdi M. 2012. E-learning sebagai media pembelajaran interaktif berbasis teknologi informasi. $J$ Ilmiah Foristek [internet]. [diunduh 2016 Mei 4]; (1): 143-152: http://scholar.google.com /scholar_url?url=http://jurnal.unta d.ac.id/jurnal/index.php/foristek/ar ticle/download/665/584

Zhang X, Dong D. 2008. Ways of identifying the opinion leaders in virtual communities. Internation al $J$ of Business and Management[internet]. [diunduh 2016 Jan 11]; 3(7): 21-27: http://citeseerx.ist.psu.edu/viewdo c/download?doi=10.1.1.464.1720 $\&$ rep=rep $1 \&$ type $=$ pdf 
ISSN 1693-3699

Jurnal Komunikasi Pembangunan Juli 2016 Vol 14, No 2

\section{Biodata Penulis}

Nama : Siska Mulyawaty

Alamat Rumah : Ciomas Hills Cluster Malabar Blok A31 No. 6 Ciomas-Bogor e-mail : siskamulyawaty@yahoo.com

Pendidikan Terakhir : S2 Jurusan Komunikasi Pembangunan Pertanian dan Pedesaan, Fakultas Ekologi Manusia, Institut Pertanian Bogor

Asal Tulisan $\quad$ : Tesis 